Chapter 3

\title{
Sedimentology and Stratigraphy of the Baynunah Formation
}

Mathieu Schuster

Université de Strasbourg \& Centre National de la Recherche Scientifique (CNRS), Institut de Physique du Globe de Strasbourg (IPGS) UMR 7516, 1 rue Blessig, 67084 Strasbourg, France mschuster@unistra.fr

\begin{abstract}
:
The Baynunah Formation (8-6 Ma) outcrops along the western coast of Abu Dhabi Emirate and has produced the only known late Miocene continental vertebrate fauna from the Arabian Peninsula. This chapter presents an overview of the geology of this formation with a focus on its stratigraphy and sedimentology. Remains of vertebrates are mainly found in the lower to middle part of this formation, which is dominated by fluvial deposits and associated paleosols containing rhizoliths and insect nests. Whitish carbonate beds occur towards the top of the formation, and preserve numerous trackways of large mammals (proboscideans and ungulates). Photographs in this chapter provide a comprehensive illustration of the most remarkable aspects of the Baynunah Formation, from outcrop conditions down to depositional structures.
\end{abstract}

Running head: Sedimentology \& stratigraphy 


\section{Introduction}

This chapter provides key information and observations on the geological context of the Baynunah Formation. The aim here is not to describe its sedimentology in detail or to discuss its stratigraphy this can be found in earlier papers - but to provide future workers with an overview of the geology of this formation, notably with illustrations of outcrops and information about its depositional environments, as a field guide would do.

The Baynunah Formation has produced, at this time, the only upper Miocene continental fossils (vertebrates, invertebrates and plants) known from the Arabian Peninsula. These fossils indicate a biochronological age for this formation between 8 and 6 Ma (Whybrow and Hill 1999; Bibi et al. 2006, this volume-a). Arabia lies at a critical junction for Old World biogeographic divisions (Hill and Whybrow 1999; Bibi 2011) and the Neogene is a crucial time period for the evolution of mammals especially for primates and early hominins (Hill 1999; Gilbert et al. 2014, this volume). The Baynunah Formation thus represents a unique window into the biogeography and evolutionary history of the fauna of Arabia. As such, geological data about this formation are crucial to help paleontologists understand the paleoenvironmental context of this fauna.

\section{FIGURE 3.1 NEAR HERE, HALF PAGE WIDTH}

\section{General context}

Outcrops of the Baynunah Formation are best exposed along the Gulf coast west of Abu Dhabi city (Figure 3.1), as discontinuous hills emerging from Quaternary and recent sedimentary cover. The Gulf is a shallow, asymmetric, Plio-Pleistocene foreland basin with a gentle slope at its southern end and a northern end which is steeper (median depth: $35 \mathrm{~m}$; maximum depth: $\sim 100 \mathrm{~m}$; sill depth: 86m; Purser \& Seibold 1973; Uchupi et al. 1999; Kassler 1973). It is associated with the Zagros orogeny, which is related to the collision of the Arabian and Eurasian plates that has been 
developing since the Oligocene ( $30 \mathrm{Ma}$, Agard et al. 2011). Large-scale maps, showing tectonic reconstructions of the Arabian plate in relation to the African and Eurasian plates, along with paleofacies evolution, have been compiled by Hempton (1987), Ziegler (2001), and Barrier and Vrielynck (2008). For the relatively short scale (time and space) represented by the Baynunah Formation, these maps only suggest continental depositional systems with no connection to the ocean. The Baynunah is only included in the synthetic paleogeography of the Gulf proposed by Hadley et al. (1998). The Gulf is considered to have been closed by the end of the Miocene (Adams et al. 1983), then flooded by seawater by the late Pliocene to mid-Pleistocene (Hadley et al. 1998; Kirkham 1998), after which it experienced repeated disconnection and drying during times of sea level lowering related to glacio-eustasy (Walkden \& Williams 1998). The modern shallow epireic sea is the result of the rise in sea level after the Last Glacial Maximum which led to a rapid reflooding of the Gulf floor (Lambeck 1996; Teller et al. 2000).

\section{FIGURES 3.2-3.4 NEAR HERE, EACH FULL PAGE WIDTH}

\section{Stratigraphy}

The late Miocene Baynunah Formation (Figs. 3.2 and 3.3), was first described by Whybrow (1989) who defined its stratotype at Jebel Barakah (Fig. 3.1). Thanks to the documentation of several complementary geological sections, Whybrow et al. (1999) refined the stratigraphic framework of the Baynunah Formation and more fully documented its spatial extent. This work also introduced a new formation, the Shuwaihat Formation, which is well exposed on the island of Shuwaihat (Figures 3.1, 3.3 and 3.4). It is also exposed in the lowermost part of the type section at Jebel Barakah, and the decision to define it as a new lithostratigraphic unit was taken on the basis of

differences in sedimentary facies (Bristow 1999; Whybrow et al. 1999). The Shuwaihat Formation consists mainly of aeolian dune deposits with prominent large-scale cross-stratified orange 
sandstones, pin-stripe laminations, grain-flow and grain-fall deposits, and sabkha to playa lake deposits including sandstones, claystones, secondary gypsum, and small-scale soft-sediment deformation structures (e.g. Bristow 1999). The geology and the paleontology of the Baynunah Formation, in contrast, point mainly to fluvial paleoenvironments (e.g. Hill and Whybrow 1999).

The Baynunah Formation is made up of continental depositional systems with both terrestrial and aquatic environments. It is typically several tens of meters thick and exceeds $50 \mathrm{~m}$ at the type section (Jebel Barakah). Locally, it is unconformably overlain by Quaternary aeolian dunes composed of wind-reworked oolites, and more often covered by recent aeolian sands (Figs. 3.3 and 3.4). The Baynunah Formation is best identified in the field by the presence of conglomerate beds, well-developed paleosols (containing rhizoliths and insect nests), its fossil content (notably continental vertebrate remains), and its whitish carbonate beds that mark the upper part of the formation. At many butte-like exposures, a cap-rock complex made of sandstone and carbonate with displacive gypsum-anhydrite and chert veins generally forms a resistant tabular top (Ditchfield et al. 1999; Whybrow et al. 1999).

The Shuwaihat and Baynunah Formations have distinct geological characteristics, however putting a sharp limit between them is not always straightforward. As noted by Bristow (1999), the contact can be erosive or transitional. Therefore both formations can be separated taking the highest sabkha or playa lake deposits as the top of Shuwaihat Formation and the lowest fluvial facies as the base of Baynunah Formation (Bristow, 1999). At Shuwaihat, the highest playa lake deposits can be found some few meters above an obvious sharp horizontal surface that truncates aeolian crossstrata, which is attributed to a Stokes surface (a wind-deflated surface, the depth of which is controlled by the water-table, Bristow and Hill 1998) and below the lowest fluvial conglomerate bed.

The most representative schematic section of the Baynunah Formation was proposed by Ditchfield (1999). It reveals a fining-upward vertical lithological evolution, from conglomerates and 
coarse sandstones in its lower part, to sandstones and limestones in its upper part. It also shows the ideal situation of a lower erosive contact of the Baynunah Formation upon the Shuwaihat Formation. The synthetic section presented in this paper (Fig. 3.2) compiles various observations made on some of the key-outcrops (Jebel Barakah, Shuwaihat, Kihal, Umm al Kabir, Gerain alAysh, Hamra, Ghayathi; map Fig. 3.1). All of these deposits were formed in a continental setting, thus limited spatial extension and lateral facies changes are typical at outcrop scale. Unfortunately, exposure conditions at many sites are much poorer today than when the pioneering work was done due to vehicular traffic, development activities, land privatization, and sand and scree cover. Therefore the existing sections (Bristow 1999; Ditchfield 1999; Whybrow et al. 1999) helped greatly to control this synthetic log.

\section{Sedimentology}

Three of the most remarkable and typical sedimentary units of the Baynunah Formation are presented here. These include the fluvial deposits and associated paleosols from the lower part of the formation and the whitish carbonates from the uppermost part of the formation.

\section{FIGURE 3.5 NEAR HERE, FULL PAGE WIDTH}

Fluvial deposits (Figure 3.5) Gravels and sands from the lower part of the Baynunah Formation, from which most of the fossils originate, were deposited by rivers as evidenced by sedimentary structures (Friend 1999). Thick (up to several meters), broad (up to several tens of meters) and upwardly thinning lenses of trough cross-stratified conglomerates are typical of the lower part of the Baynunah Formation (Fig. 3.3). They are remarkable for their clasts, which are made of reworked pedogenetic carbonate derived from older paleosols (Ditchfield 1999; Friend 1999). Many have irregular nodular shapes, but some show a typical root-like morphology (elongated, circular section, 
branching pattern). These clasts are mainly sandstone cemented by carbonate and range in size from granules to cobbles. They likely derive from the rhizoliths that are very common in the Baynunah Formation (see below). Among these clasts, it is worth noting that some of them are enclosed by a thin layer (up to $1 \mathrm{~cm}$ ) of very finely laminated pure carbonate (Fig. 3.4). Oncoids are here reported for the first time within the conglomerates of the Baynunah Formation. Oncoids form in various types of aquatic environments, notably in river streams or in the nearshore areas of marine or continental water-bodies. These oncoids, which here only appear as reworked clasts in the fluvial conglomerates, show possible evidence for paleolakes, now no longer preserved themselves. The trough cross-stratified conglomerate beds of the Baynunah Formation have been interpreted as of fluvial origin. The Baynunah rivers, with a local flow directions towards the ESE, have been proposed to be part of an ancestral Tigris-Euphrates river system (Friend 1999). More generally, fluvial depositional environments, from the main channel axis up to the alluvial floodplain, are also suggested by cross-bedded sandstones, mudstone rip-up clasts, inclined heterolithic stratifications, climbing ripples, laminations and terrestrial bioturbations.

\section{FIGURE 3.6 NEAR HERE, FULL PAGE WIDTH}

\section{Paleosols (Figure 3.6)}

Paleosols are well-developed in the Baynunah Formation, whereas only sparse rhizoliths and insect galleries and nests can be observed in the underlying Shuwaihat Formation. Paleosols are thus a distinguishing feature of the Baynunah Formation. However, they have received only scant attention that mainly outlined the presence of root related sedimentary structures (Glennie and Evamy 1968; Whybrow and McClure 1981; Friend 1999). Rhizoliths are indeed extremely wellrepresented in the sandstones, in the form of root molds, root casts, root tubules and rhizocretions. They are associated with galleries and nests of termites and possibly dung beetle brood-balls. The 
presence of termite and ant nests has been previously reported from the Miocene of Abu Dhabi (Bown and Genise 1993). Comparable insect nests are common in penecontemporaneous terrestrial strata of Africa (e.g. Schuster et al. 2009), and some of the termite nests closely resemble the Vondrichnus planoglobus chambers described from the Chad Basin (Duringer et al. 2007). Rhizoliths and insect nests are organized in sometimes thick beds (up to several meters) forming extensive paleosol horizons characterized by various colors (red, green, white). These bioturbations are highlighted by colour changes, and by differential erosion. Where they are most abundant, primary sedimentary structures are completely overprinted, while elsewhere some can still be inferred. Thus, they evidently developed after the river flooded and after the deposition of fluvial bedforms, above the water-table, and before the next flood which might have reworked part of the pedogenic concretions. The prominence and the degree of preservation of some paleosol beds and the presence of soil-derived clasts within the conglomerates, suggest that in some places on the landscape (e.g. emerged fluvial bars, distal floodplains, abandoned channels) paleosols were able to sufficiently develop and mature before being reworked.

\section{FIGURE 3.7 NEAR HERE, FULL PAGE WIDTH}

\section{Carbonate beds (Figure 3.7)}

Whitish carbonate beds (up to several tens of centimetres thick) alternate with variably cemented sandstone beds and are typical of the upper Baynunah Formation. They outcrop in section as prominent tabular beds, or can be aerially exposed as extensive wind-deflated surfaces. They have until now received only scant attention, likely because vertebrate remains mainly derive from underlying siliciclastic levels. They have been briefly described as "poorly consolidated micritic limestones" and "fenestral micrites" in which shell molds of possible cerithid gastropods have been observed, and were considered to have been deposited in marine to brackish waters (Ditchfield 
1999). Analyses of ostracods, charophytes, and pollen (Mazzini \& Kovacova, this volume) show that these carbonates formed in shallow, freshwater environments that flooded and desiccated repeatedly, and with no evidence of any marine connections. These whitish carbonate beds show only few sedimentary structures, dominated by crude horizontal bedding, fine horizontal laminations, and rare bioturbations. When exposed as horizontal surfaces, as at Mleisa, they can reveal remarkable trackways of large mammals among wide desiccation cracks and polygons (Bibi et al., 2012, this volume-b; Schuster et al., in prep). These carbonate beds can be almost pure calcite but also often contain a variable amount of clastics (clay, silt and sand). Their apparently constant individual thickness at the size of available exposures suggests a wide original lateral extent.

\section{Acknowledgements}

I am grateful to Faysal Bibi who invited me to come and see the famous outcrops of the Miocene of Abu Dhabi. Faysal, Andrew Hill, Mark Beech, and Brian Kratz welcomed me into their group and were great field companions. They are warmly thanked for their unlimited patience. L.J. McHenry and E. Roberts helped improving an earlier version of this text. Fieldwork was supported by the Abu Dhabi Department of Culture and Tourism (DCT, formerly the Tourism and Culture Authority, formerly the Authority for Culture and Heritage) and the Institut de Paléoprimatologie, Paléontologie Humaine: Évolution et Paléoenvironnements (iPHEP) at the University of Poitiers (currently PALEVOPRIM, UMR CNRS 7262).

\section{References}

Adams, C.G., Gentry, A.W., \& Whybrow, P.J. (1983). Dating the terminal Tethyan event. In J. Meulenkamp (Ed.), Reconstruction of Marine Environments, Utrecht Micropaleontological 
Bulletins, 30, 273-298 .

Agard, P., Omrani, J., Jolivet, L., Whitechurch, H., Vrielynck, B., Spakman, W., et al. (2011). Zagros orogeny: a subduction-dominated process. Geological Magazine, 148, 692-725.

Barrier. E., \& Vrielynck, B. (2008). Palaeotectonic maps of the Middle East. Tectono-sedimentarypalinspastic maps from Late Norian to Pliocene. 14 maps. Paris: CGMW/CCGM.

Bibi, F., Shabel, A.B., Kraatz, B.P., \& Stidham, T.A. (2006). New fossil ratite (Aves: Palaeognathae) eggshell discoveries from the Late Miocene Baynunah Formation of the United Arab Emirates, Arabian Peninsula. Palaeontologia Electronica, 9 (1), http://palaeo-electronica.org/pal eo/2006_1/eggshell/issue1_06.htm

Bibi. F. (2011). Mio-Pliocene Faunal Exchanges and African Biogeography: The Record of Fossil Bovids. PLoS ONE, 6(2), e16688, https://doi.org/10.1371/journal.pone.0016688

Bibi, F., Kraatz, B., Craig, N., Beech, M., Schuster, M., \& Hill, A. (2012). Early evidence for complex social structure in Proboscidea from a late Miocene trackway site in the United Arab Emirates. Biology Letters, 8(4), 670-673, doi: 10.1098/rsbl.2011.1185rsbl20111185

Bibi, F., Hill, A., Beech, M., \& Yasin, W. (2013). Late Miocene fossils from the Baynunah Formation, United Arab Emirates: Summary of a decade of new work. In L. Flynn, X. Wang, \& M. Fortelius, (Eds.), Neogene Terrestrial Mammalian Biostratigraphy and Chronology in Asia (pp. 583-594). New York: Columbia University Press.

Bibi, F., Kaya, F., Varela, S. (this volume-a). Paleoecology and Paleobiogeography of the Baynunah Fauna. In F. Bibi, B. Kraatz, M. Beech, \& A. Hill (eds.) Sands of Time: Late Miocene Fossils from the Baynunah Formation, U.A.E. (pp. xxx). Cham: Springer.

Bibi, F., Kraatz, B., Beech, M., \& Hill., A. (this volume-b). Fossil Trackways of the Baynunah Formation. In F. Bibi, B. Kraatz, M. Beech, \& A. Hill (eds.) Sands of Time: Late Miocene Fossils from the Baynunah Formation, U.A.E. (pp. xxx). Cham: Springer.

Bown, T.M., \& Genise, J.F. (1993). Fossil nests and gallery systems of termites (isoptera) and ants 
(formicidae) from the Early Miocene of Southern Ethiopia and the late Miocene of Abu Dhabi Emirate, U.A.E. Geological Society of America, 89th Annual Cordilleran Section Meeting and 46th Annual Rocky Mountain Section Meeting. Abstracts with Programms, 25 (6), 58.

Bristow, C.S. (1999). Aeolian and sabkha sediments in the Miocene Shuwaihat Formation, Emirate of Abu Dhabi, United Arab Emirates. In P.J. Whybrow, \& A. Hill (Eds). Fossil vertebrates of Arabia, with emphasis on the Late Miocene faunas, geology, and palaeoenvironments of the Emirate of Abu Dhabi, United Arab Emirates (pp. 50-60). New Haven: Yale University Press.

Bristow, C.S., \& Hill, N. (1998). Dune morphology and palaeowinds from aeolian sandstones in the Miocene Shuwaihat Formation, Abu Dhabi, United Arab Emirates. In A.S. Alsharhan, K.W. Glennie, G.L. Whittle, \& C.G.St.C. Kendall (Eds). Quaternary Deserts and Climatic Change (pp. 553-564). Rotterdam: Balkema.

Ditchfield, P.W. (1999). Diagenesis of the Baynunah, Shuwaihat, and upper Dam Formation sediments exposed in the Western Region, Emirate of Abu Dhabi, United Arab Emirates. In P.J. Whybrow, \& A. Hill (Eds). Fossil vertebrates of Arabia, with emphasis on the Late Miocene faunas, geology, and palaeoenvironments of the Emirate of Abu Dhabi, United Arab Emirates (pp. 61-74). New Haven: Yale University Press.

Duringer, P., Schuster, M., Genise, J.F., Brunet, M., \& Vignaud, P. (2007). New trace fossils of termites, nests and galleries, from the Chad Basin (Upper Miocene and Pliocene), Paleogeography, Paleoclimatology, Paleoecology, 251, 323-353.

Friend, P.J. (1999). Rivers of the Lower Baynunah Formation, Emirate of Abu Dhabi, United Arab Emirates. In P.J. Whybrow, \& A. Hill (Eds). Fossil vertebrates of Arabia, with emphasis on the Late Miocene faunas, geology, and palaeoenvironments of the Emirate of Abu Dhabi, United Arab Emirates (pp. 38-49). New Haven: Yale University Press.

Gilbert, C.C., Bibi, F., Hill, A., \& Beech, M.J. (2014). Early guenon from the late Miocene Baynunah Formation, Abu Dhabi, with implications for cercopithecoid biogeography and evolution. 
Proceedings of the National Academy of Sciences of the United States of America, 111 (28), 1011910124, https://doi.org/10.1073/pnas.1323888111

Gilbert C. C., \& Hill A. (this volume) Primates from the Baynunah Formation, in F. Bibi, B. Kraatz, M. Beech, \& A. Hill (eds.) Sands of Time: Late Miocene Fossils from the Baynunah Formation, U.A.E. (pp. xxx). Cham: Springer.

Glennie, K.W., \& Evamy, B.D. (1968). Dikaka: plants and plant-root structures associated with aeolian sand. Palaeogeography, Palaeoclimatology, Palaeoecology, 4, 77-87.

Hadley, D.G., Brouwers, E.M., \& Bown, T.M. (1998). Quaternary palaeodunes, Arabian Gulf Coast,Abu Dhabi Emirate: age and palaeoenvironmental evolution. In A.S. Alsharhan, K.W. Glennie, G.L. Whittle, \& C.G.ST.C. Kendall (Eds). Quaternary Deserts and Climatic Change (pp. 123-139). Rotterdam: Balkema.

Hempton, M.R. (1987). Constraints on Arabian plate motion and extensional history of the Red Sea. Tectonics 6, 687-705.

Hill., A. (1999) Late Miocene sub-Saharan African vertebrates, and their relation to the Baynunah fauna, Emirates of Abu Dhabi, United Arab Emirates. In P.J. Whybrow, \& A. Hill (Eds). Fossil vertebrates of Arabia, with emphasis on the Late Miocene faunas, geology, and palaeoenvironments of the Emirate of Abu Dhabi, United Arab Emirates (pp. 420-429). New Haven: Yale University Press.

Hill, A., \& Whybrow, P. (1999). Summary and overview of the Baynunah fauna, Emirate of Abu Dhabi, and its context. In P.J. Whybrow, \& A. Hill (Eds). Fossil vertebrates of Arabia, with emphasis on the Late Miocene faunas, geology, and palaeoenvironments of the Emirate of Abu Dhabi, United Arab Emirates, (pp. 7-14). New Haven: Yale University Press.

Hill, A., Bibi, F., Beech, M., \& al-Tikriti, W.Y. (2012). Before archaeology: life and environments in the Miocene of Abu Dhabi. In D. Potts, \& P. Hellyer (Eds). Fifty Years of Emirates Archaeology. Ministry of Culture, Youth and Community Development (pp. 20-33). Abu Dhabi, UAE. 
Kassler, P. (1973). The structural and geomorphic evolution of the Persian Gulf. In B.H. Purser (Ed). The Persian Gulf. Holocene Carbonate Sedimentation and Diagenesis in a Shallow Epicontinental Sea (pp. 11-32). New York: Springer.

Kirkham, A. (1998). A Quaternary proximal foreland ramp and its continental fringe, Arabian Gulf, UAE . In V.P. Wright, \& T.P. Burchette (Eds). Carbonate Ramps. Geological Society, London, Special Publications, 149, 15-41.

Lambeck, K. (1996). Shoreline reconstructions for the Persian Gulf since the last glacial maximum. Earth and Planetary Science Letters, 142, 43-57.

Mazzini, I. \& Kovacova, M. (this volume). Ostracods, charophytes, and pollen from the Baynunah Formation. In F. Bibi, B. Kraatz, M. Beech, \& A. Hill (eds.) Sands of Time: Late Miocene Fossils from the Baynunah Formation, U.A.E. (pp. xxx). Cham: Springer.

Purser, B.H., \& Seibold, E. (1973). The principal environmental factors influencing Holocene sedimentation and diagenesis in the Persian Gulf. In B.H. Purser (Ed). The Persian Gulf. Holocene Carbonate Sedimentation and Diagenesis in a Shallow Epicontinental Sea (pp. 1-10). New York: Springer.

Schuster, M., Duringer, P., Ghienne, J.F., Roquin, C., Sepulchre, P., Moussa, A., et al. (2009). Chad Basin: Paleoenvironments of the Sahara since the Late Miocene . Comptes Rendus Geoscience, 341, $603-611$.

Teller, J.T., Glennie, K.W., Lancaster, N., \& Singhvi, A.K. (2000). Calcareous dunes of the United Arab Emirates and Noah's Flood: the postglacial reflooding of the Persian (Arabian) Gulf. Quaternary International, 68, 297-308.

Uchupi, E., Swift, S.A., \& Ross, D.A. (1999). Late Quaternary stratigraphy, Paleoclimate and neotectonism of the Persian (Arabian) Gulf region. Marine Geology, 160, 1-23.

Walkden, G., \& Williams, A. (1998). Carbonate ramps and the Pleistocene-Recent depositional systems of the Arabian Gluf. In V.P. Wright, \& T.P. Burchette (Eds). Carbonate Ramps. Geological Society, London, Special Publications, 149, 4-53. 
Whybrow P.J. (1989). New stratotype; the Baynunah Formation (Late Miocene), United Arab Emirates: Lithology and palaeontology. Newsletters on Stratigraphy, 21, 1-9.

Whybrow, P.J., \& Hill, A. (Eds). (1999). Fossil vertebrates of Arabia, with emphasis on the Late Miocene faunas, geology, and palaeoenvironments of the Emirate of Abu Dhabi, United Arab Emirates. New Haven: Yale University Press.

Whybrow, P.J., Friend, P.J., Ditchfield, P.W., \& Bristow, C.S. (1999). Local stratigraphy of the Neogene outcrops of the coastal area: Western Region, Emirate of Abu Dhabi, United Arab Emirates. In P.J. Whybrow, \& A. Hill (Eds). Fossil vertebrates of Arabia, with emphasis on the Late Miocene faunas, geology, and palaeoenvironments of the Emirate of Abu Dhabi, United Arab Emirates (pp. 28-37). New Haven: Yale University Press.

Whybrow, P.J., \& McClure, H.A. (1981). Fossil mangrove roots and palaeoenvironments of the Miocene of the eastern Arabian peninsula. Palaeogeography, Palaeoclimatology, Palaeoecology, $32,213-225$.

Ziegler, M.A. (2001). Late Permian to Holocene Paleofacies Evolution of the Arabian Plate and its Hydrocarbon Occurrences. GeoArabia 6, 445-501. 


\section{Figure captions}

\section{Figure 3.1}

Location maps of the study area with names of the main localities mentioned in the text (world map generated with Marble/Ubuntu; Landsat TM 2000 view of the Emirate of Abu Dhabi from earthexplorer.usgs.gov) [HALF PAGE WIDTH]

\section{Figure 3.2}

Synthetic log of the Baynunah Formation A, and general field views of the main sedimentological components of the section (B-F). Note that the limestone and the caprock beds protrude not because they are composed of coarse material but because they are much more lithified than the other beds. Locations: B, Shuwaihat, SHU 2. C-D, Gerain al-Aysh. E, Kihal. F, Gerain al-Aysh. [FULL PAGE WIDTH]

\section{Figure 3.3}

General views of exposure conditions of the Baynunah Formation. A, lower and B, upper parts of the formation (Jebel Barakah). C, orange cross-stratified beds of the Shuwaihat Formation in the foreground (Shuwaihat). D, coarse scree slopes derived from the erosion of overlying conglomeratic beds of the lower part of the formation (Gerain al-Aysh). E, fluvial beds of the lower Baynunah (Thumayriyah island). F, upper part of the formation (Gerain al-Aysh). Note the prominent whitish beds and cap rock topping the buttes, and the deflated remains of this cap rock (mainly cherts) in the foreground. [FULL PAGE WIDTH]

\section{Figure 3.4}


Miocene (Shuwaihat Formation; A-C) and Quaternary (D-E) aeolian dune deposits observed below and above the Baynunah Formation respectively. A, vertical and B, horizontal cross-sections of aeolian dune cross-stratification (Shuwaihat). C, sparse rhizoliths and/or bioturbation in the aeolian sands (Shuwaihat). D, large-scale aeolian dune cross-stratification of Quaternary aeolianites made of oolitic sands as shown in E, (Hadwaniyya). [FULL PAGE WIDTH]

\section{Figure 3.5}

Fluvial deposits of the Baynunah Formation. A-B, trough cross-stratified conglomerates in vertical cross section. C, plane bed view of trough cross-stratified sets of conglomerate, showing a paleoflow toward the east. D, crudely laminated, clast-supported conglomeratic bed made of intraformational clasts. E-F, bones (arrows) as clasts within the conglomerate. G, crocodile skull (outlined by a dashed line) in planar cross-laminated sands. H-I, example of a lens of conglomerate with reworked oncoids as clasts (arrow heads). J, cross-section of an oncoid showing its nucleus (sandstone) encircled by millimetre-scale laminations of carbonate. [FULL PAGE WIDTH]

\section{Figure 3.6}

Paleosols of the Baynunah Formation. A-C, rhizoliths collected as part of rock fragments comprising present-day deflation lag. D, discrete root tubules overprinting current ripple laminations in sandstones. E, an extremely dense network of rhizoliths from which the hosting sediment has been removed by differential erosion. Note the branching and diameter changes typical of roots. F-G, Vondrichnus-like Termite nests (arrow heads) revealed by weathering (color change and erosion); note the complex network of rhizoliths, burrows, and galleries. H, spheroidal bioturbation (arrow heads) possibly corresponding to dung-beetle brood balls found in a dense network of petrified roots. I, plane bed view of a partly preserved termite nest exhibiting internal concentric laminations with apex oriented toward the entrance gallery (arrow head), a typical 
feature of Vondrichnus. [FULL PAGE WIDTH]

\section{Figure 3.7}

Whitish carbonate beds from the upper Baynunah Formation. A-B, general views showing white beds (white arrows) of continuous thickness at outcrop scale, and the caprock (black arrows) forming the tabular top of the buttes, at Kihal and Mleisa 2, respectively. C-D, displacive evaporites (gypsum-anhydrite) interbedded with laminated and sandy white limestones (C, Mleisa 2. D, Gerain al-Aysh). E-F, carbonate surface at Mleisa 1 showing well-preserved desiccation cracks and polygons, as well as proboscidean trackways (individual footprints indicated by arrows). [FULL PAGE WIDTH] 


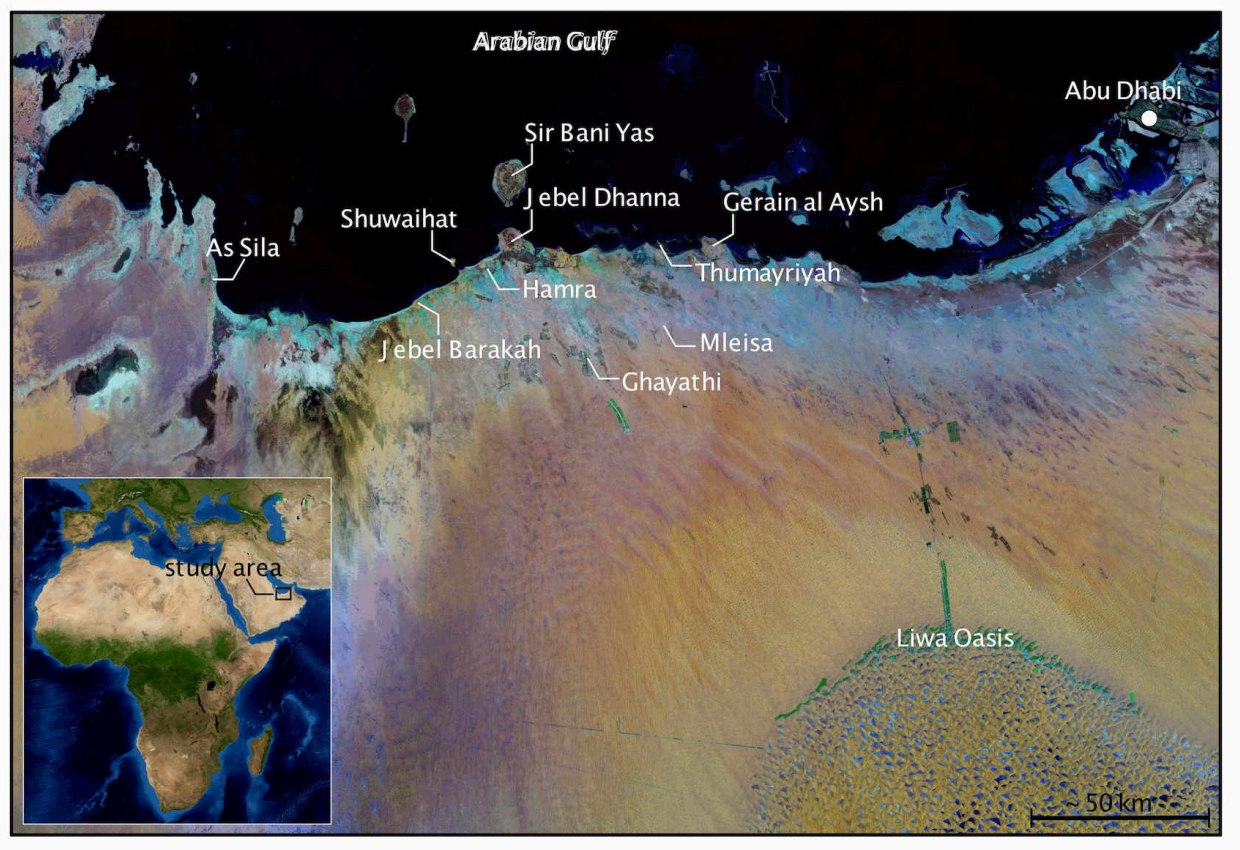

Figure 1 


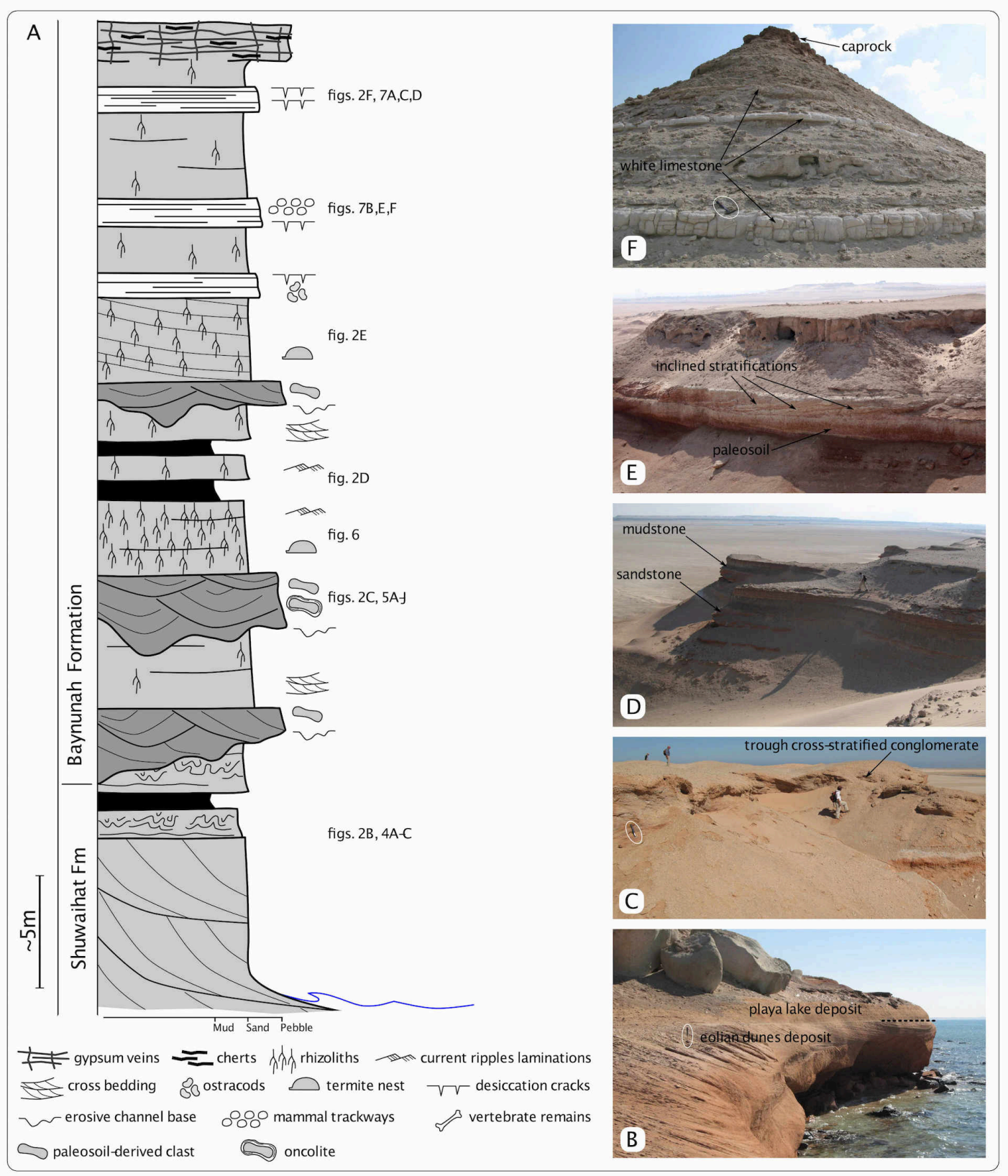

Figure 2 

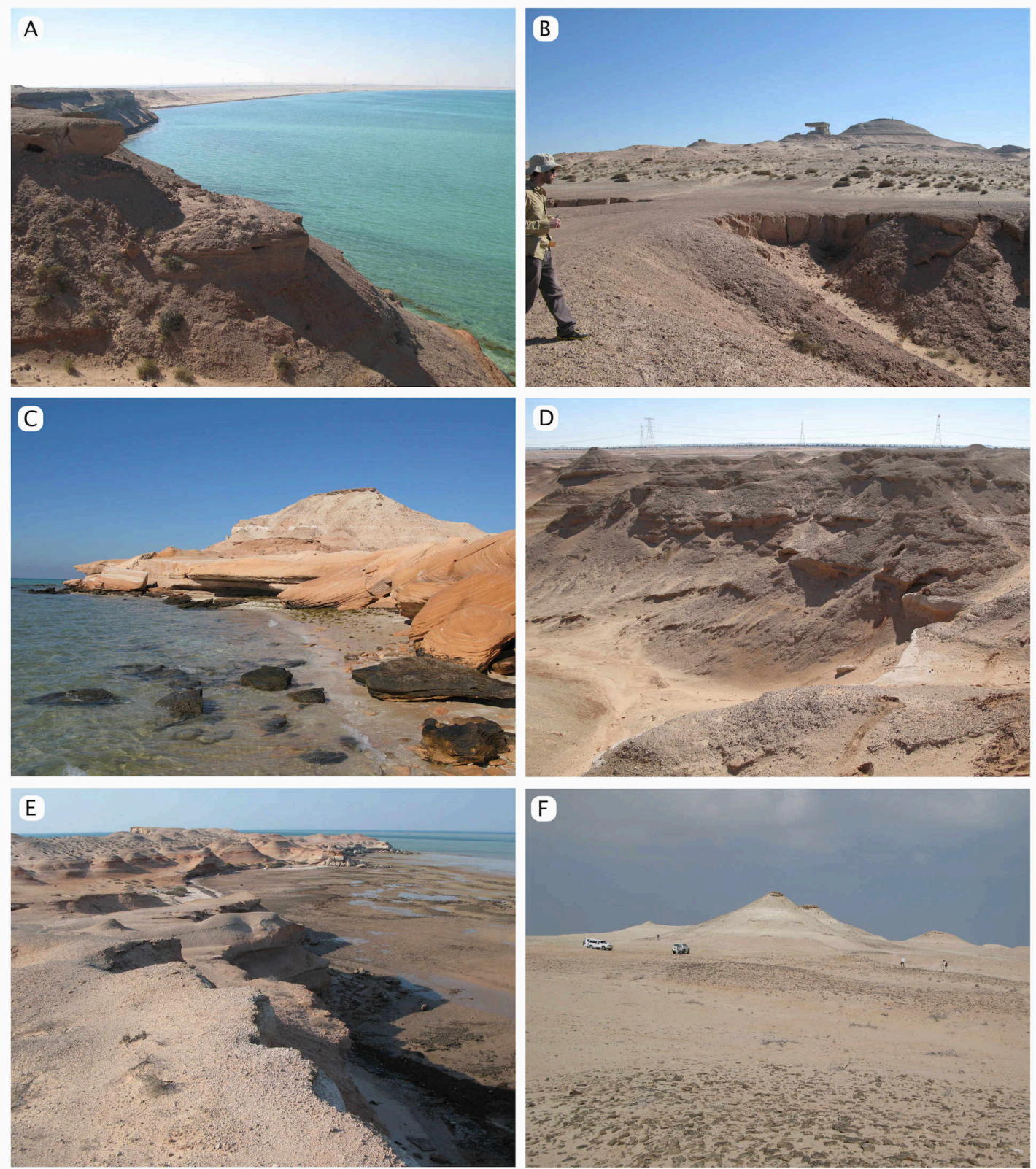

Figure 3 

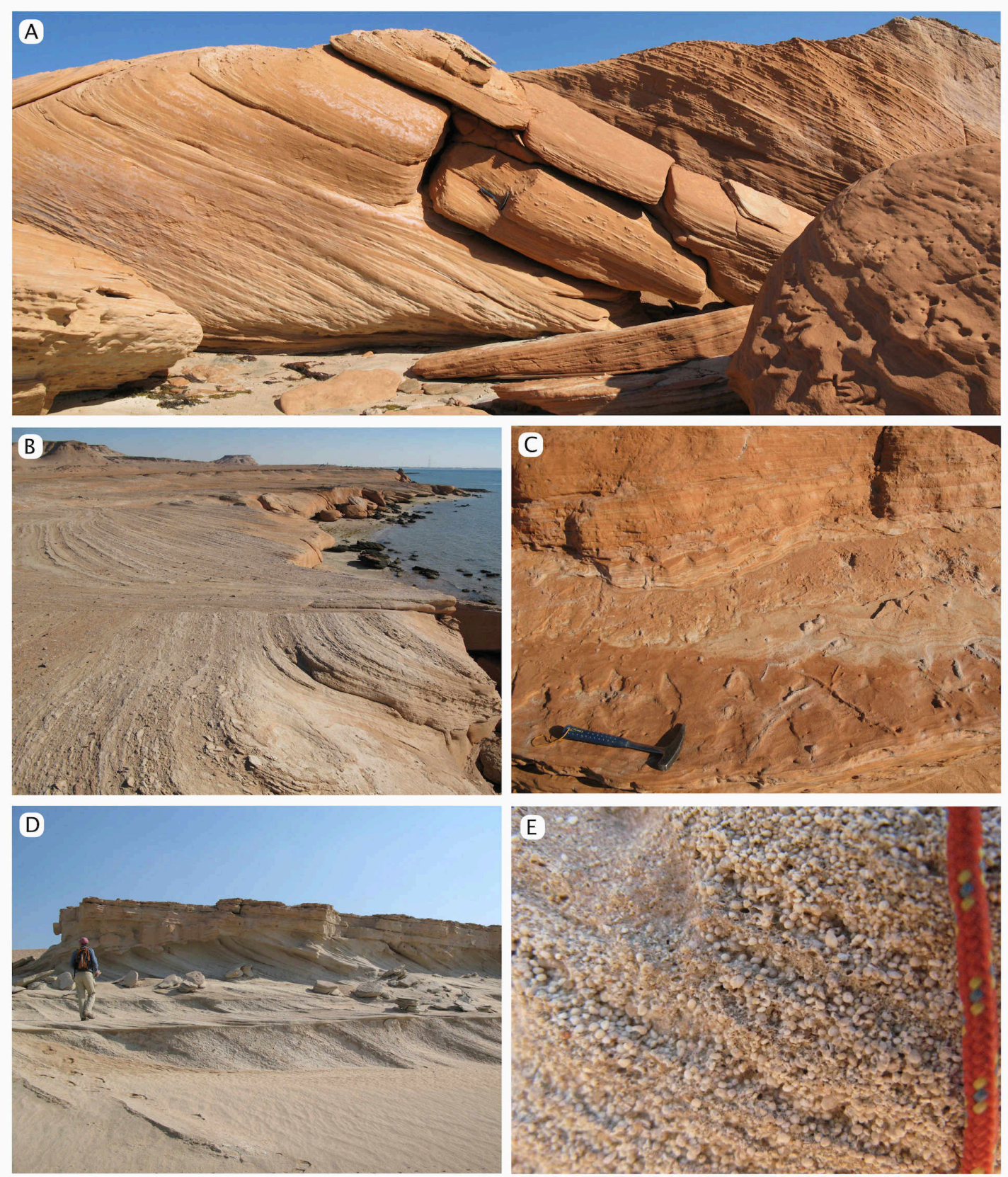

Figure 4 

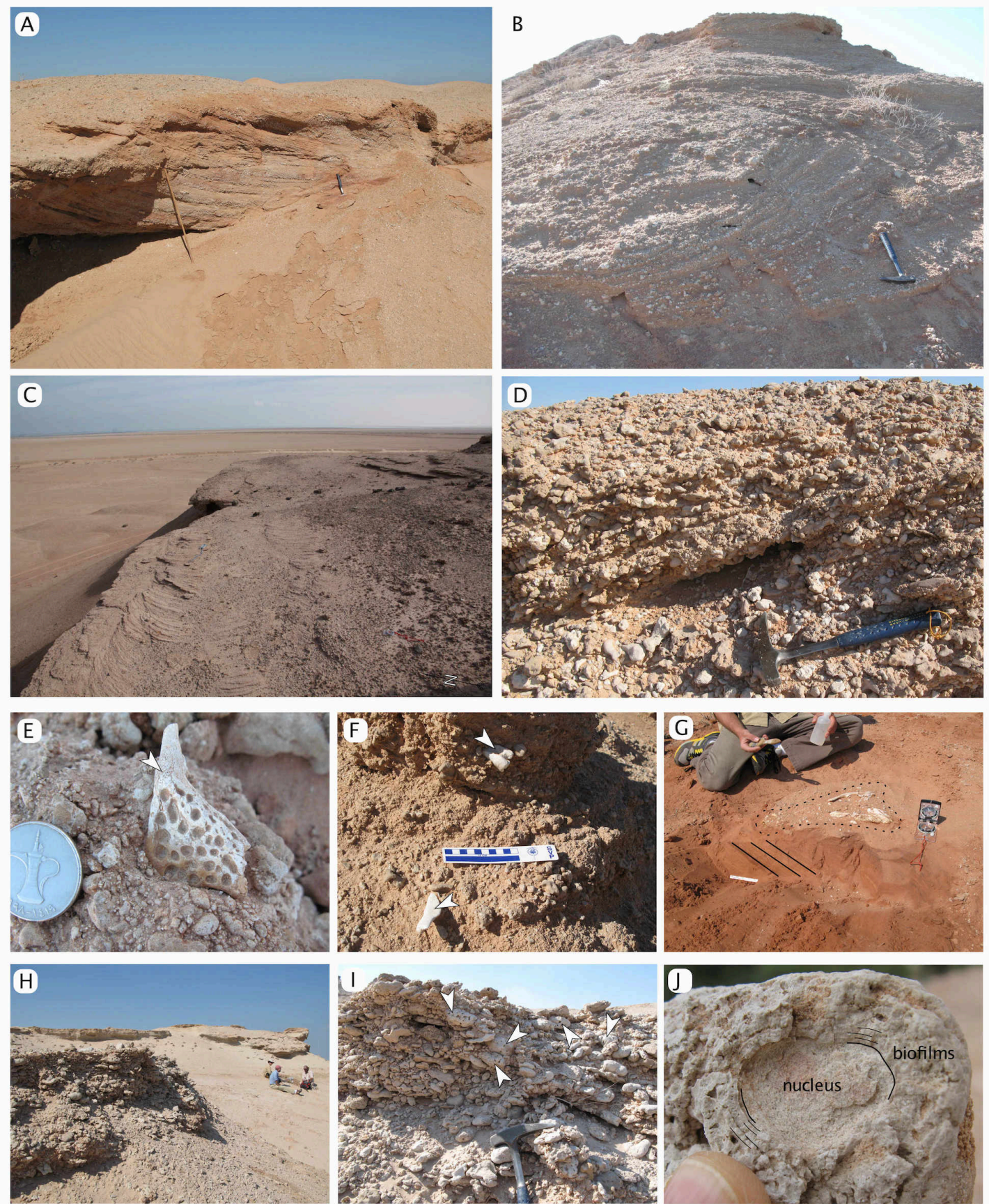

Figure 5 

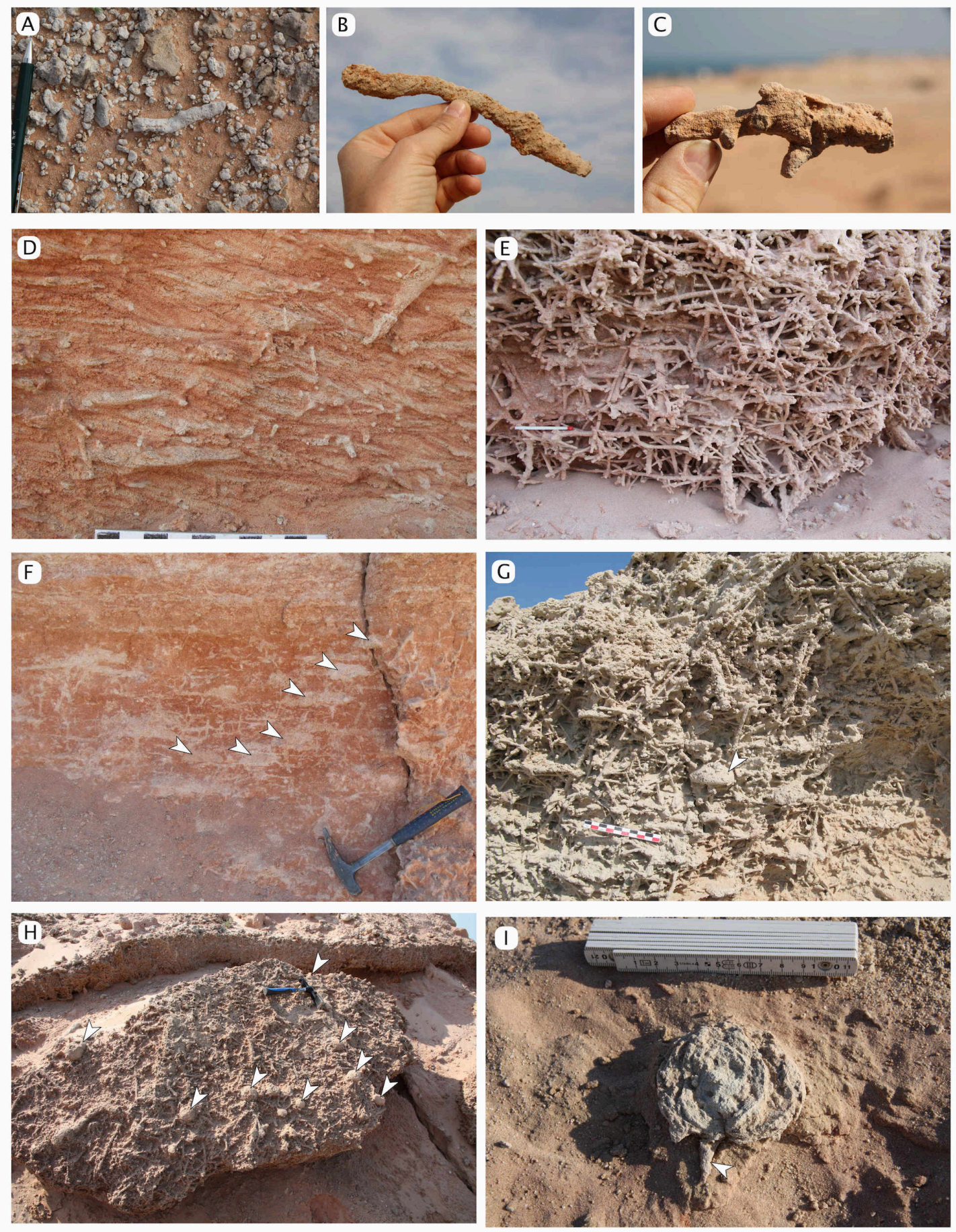

Figure 6 

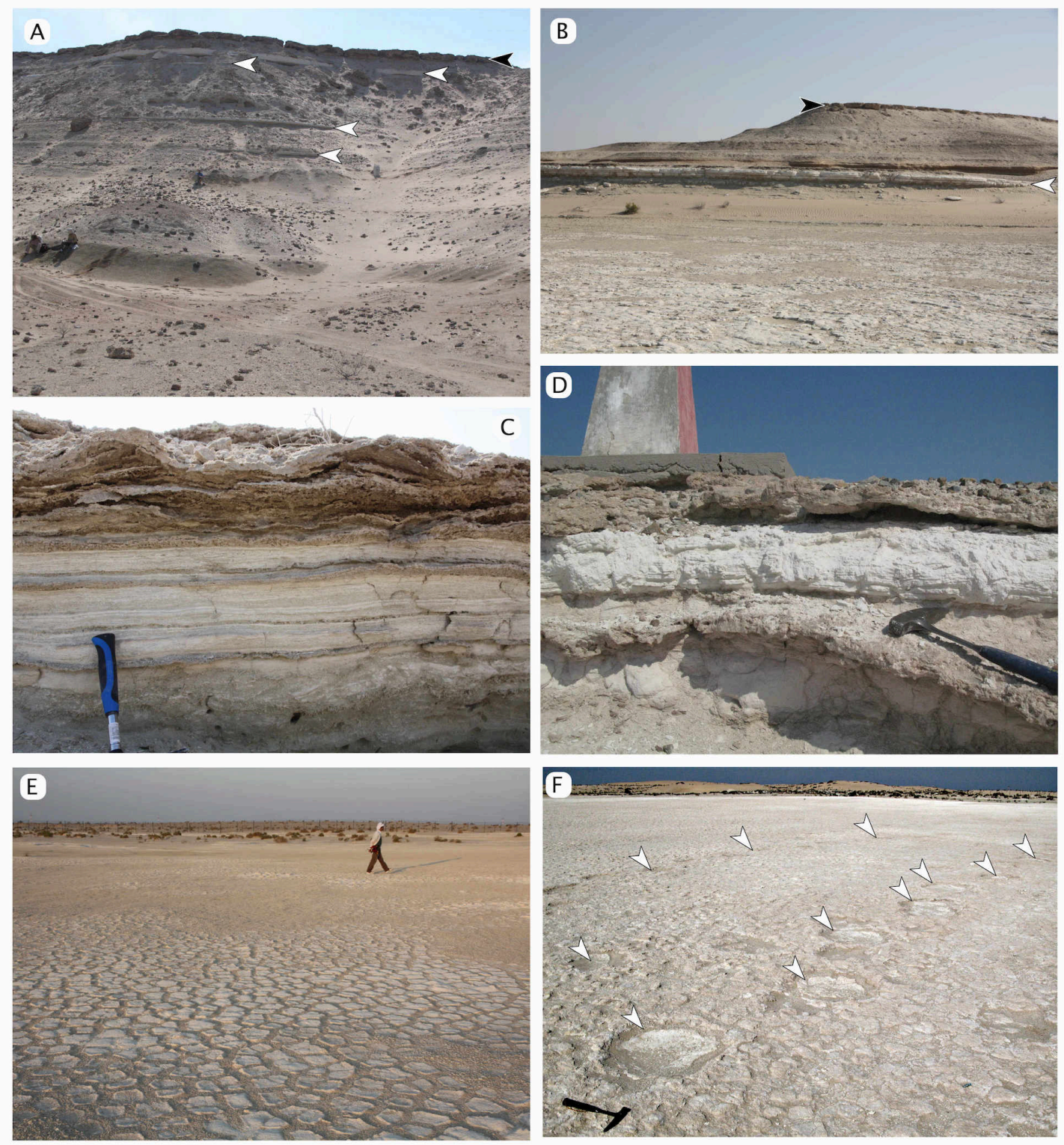

Figure 7 